\title{
Development of 5-E Learning Cycle-Based Simple Chemistry Practicum Guideline Module for Eleventh Grade
}

\author{
Salsabila Syifaunnida1 ${ }^{*}$, Agus Kamaludin ${ }^{1}$ \\ ${ }^{1}$ Chemistry Education Department, Universitas Islam Negeri Sunan Kalijaga, Yogyakarta, Indonesia.
}

DOI: $10.29303 /$ jppipa.v8i1.988

\section{Article Info}

Received: September 22, 2021

Revised: January 5, 2022

Accepted: January 10, 2022

Published: January 31, 2022

\begin{abstract}
The chemistry practicum activity in school is impossible due to the COVID-19 pandemic, whereas practicum is very important to train soft skills and understanding of chemistry materials. This research aimed to develop 5-e learning cycle-based simple chemistry practicum guideline module for students of class XI. The development model used was a 4-D development model. The quality of the product was assessed by one material expert, one media expert, five reviewers (chemistry teachers of high school), and responded by ten students of high school. The instruments used in the research were product quality assessment sheets using a Likert scale and student response sheets, in the form of a questionnaire, using the Guttman scale. The characteristics of the developed practicum module were in the form of a practicum module for hydrocarbons, thermochemistry, reaction rates, and chemical equilibrium, using simple tools and chemicals; being combined with the 5-e learning cycle model. The quality assessment on the practicum module, which was carried out by one material expert, media experts, and reviewers, gained 88.89. 95.83. and 94.00\%. All assessments got a score with Very Good score. From these results, it can be concluded that the developed product is feasible to be used as a practicum guideline.
\end{abstract}

Keywords: Module; Chemistry Practicum; 5-E Learning Cycle

Citation: Syifaunnida, S., \& Kamaludin, A. (2022). Development of 5-E Learning Cycle-Based Simple Chemistry Practicum Guideline Module for Eleventh Grade. Jurnal Penelitian Pendidikan IPA, 8(1), 156-162. https://doi.org/10.29303/jppipa.v8i1.988

\section{Introduction}

The development of soft skills is the master key to deal with the changes in the era of fourth industrial revolution (Samad, 2020). In this era, information technology has become the main basis in human's daily life (Yuliati \& Saputra, 2019). The progress of science and technology automatically makes the competition of human's competency tighter (Gotama, 2018). Based on the results of studies by the Stanford Research Institute and Carneige Mellon Foundation, it shown that $75 \%$ of long-term job success depends on soft skills and $25 \%$ is determined by hard skills (Rashidi, et al., 2013). Here, the soft skills include the ability to think critically, creativity, communication, and collaboration (Redhana, 2019). However, the reality on the ground shows that education in Indonesia is more oriented towards the cultivation of hard skills and has not been much oriented to the formation of soft skills (Wisetya \& Ismara, 2018). As a result, students have not been able to develop their soft skills optimally.

The development of students' soft skills can be optimized through learning with a scientific approach (Redhana, 2019). The scientific approach has several characteristics. Those are student-centered learning, involving science process skills in constructing concept, stimulating the development of intelligence (thinking skills), and being able to develop students' character (Mulyati, 2020). Learning with a scientific approach can be applied to science subjects. One of which is chemistry (Widyasti, et al., 2020). Chemistry has two inseparable main things, namely, chemistry as a product (chemical knowledge in the form of fact, concept, principle, law, and theory) or scientific 
finding, and chemistry as a process (scientific work) (Faizan, 2020). This does not rule out the possibility of difficulties for students to participate the chemistry learning. According to the results of interviews with students of high school in Yogyakarta, the majority of chemistry materials contain abstract concepts which get students experiencing difficulties to understand it.

One of learning methods that can be applied to support students' understanding of chemistry is practicum (Suryaningsih, 2017). Practicum is an experiment-based teaching and learning activity (Rahmawati \& Khamidinal, 2019). Experiment-based learning directs students to experiential learning (learning based on concrete experience). Thus, students have opportunity to find out and prove the theories that have been studied by themselves (Suryaningsih, 2017). In addition, students can also develop soft skills which include observation, data analysis, problem solving, teamwork, and communication skills (Amarlita, 2019). In accordance with the research by Sari and Mauliza (2020), it stated that not all teachers implement the practical activities in the learning process. This is due to the instruments and chemicals are quite expensive and the unavailability of laboratory assistants is an obstacle to implement practicum in schools. In addition, during the current COVID-19 pandemic, it is also not possible to carry out practicum (Sugiharti \& Sugandi, 2020). Meanwhile, to deliver the majority of chemistry materials, especially in class XI, practical activities are required.

The ordinary chemistry practicum can be used as an alternative to overcome any obstacle in carrying out practicum in the laboratory, especially during the COVID-19 pandemic (Hendriyani \& Novi, 2020). This is due to the instruments and materials which are used to perform the simple practicum come from the surroundings, so that practicum activity can still be implemented even though it is not performed in the laboratory. The learning activity by using a simple practicum is considered to be able to provide good motivation in order to foster students' interest in learning. Eventually, students can gain thorough understanding when studying chemistry (Baunsele, et al., 2020). Furthermore, the practicum guidelines are required in order that the practicum activity can run smoothly and effectively (Yuniar, et al., 2019). The practicum guidelines are required in order that practicum activities by students can achieve the competencies to be achieved (Amarlita, 2019). However, based on the results of interviews with chemistry teachers of high school in Yogyakarta, it was stated that the available practicum guideline module has not used simple tools and materials and it has not been able to develop students' soft skills. Here, the soft skills include problem solving skills and creative thinking skills.
Any effort that can be made to solve the problems above is to integrate the practicum guideline module with a learning model that can develop students' soft skills (Khairunnufus, et al., 2018). One of the learning models that can be applied is model of 5-e learning cycle (Adriyani \& Purwanti, 2018). The model of 5-e learning cycle allows active learning and develops students' abilities to communicate, to relate various science topics, and to apply complex concepts (Pambudi et al., 2016). The 5-e learning cycle model can also improve students' science process skills (Adriyani \& Purwanti, 2018). Nevertheless, based on the literature study that has been carried out, there has not been much research on the development of 5-e learning cycle-based practicum guideline module, especially on chemistry for class XI.

The previous research conducted by Utami (2019) has similar topic but it was limited to the materials of alkane derivative carbon compounds for class XII. In addition, research conducted by Setyowati (2016), was limited to the materials of class X. Therefore, 5-E learning cycle-based simple chemistry practicum guideline module for eleventh grade needs to be developed.

This research aims to develop a simple chemistry practicum guideline module based on the 5-e learning cycle for class XI and to determine the quality and response of students toward the product. Hopefully, the practicum guideline module can be used as a guideline during performing practicum and help develop students' soft skills.

\section{Method}

This research is a development research (R\&D) which uses a 4-D development model (define, design, develop, disseminate). However, this research was limited to the stage of development. The developed product was assessed by one media expert, one material expert, and five reviewers (chemistry teachers of high school) and it was also responded by ten students of eleventh grade majoring in mathematics and natural science.

The instruments used in this research included product validation sheets, product quality assessment sheets, and student response sheets. The assessment of product quality was conducted by using Likert-scale questionnaire while student responses were obtained through Guttman-scale questionnaire.

The data analysis technique of the product quality assessment was carried out by converting the qualitative assessment to quantitative (score). Likertscale was used to convert the qualitative assessment to quantitative (score). The obtained score was then calculated in order to determine the average score for the whole and each aspect of the assessment. 
Furthermore, the score was then converted into a qualitative value according to the ideal assessment category as shown in Table 1.

Table 1. Ideal Assessment Criteria

\begin{tabular}{ll}
\hline Score Range & Category \\
\hline $\mathrm{X} \geq \overline{\mathrm{X}}_{\mathrm{i}}+\mathrm{SB}_{\mathrm{x}}$ & Very Good \\
$\overline{\mathrm{X}}_{\mathrm{i}}+\mathrm{SB}_{\mathrm{x}}>\mathrm{X} \geq \overline{\mathrm{X}}_{\mathrm{i}}$ & Good \\
$\overline{\mathrm{X}}_{\mathrm{i}}>\mathrm{X} \geq \overline{\mathrm{X}}_{\mathrm{i}}-\mathrm{SB}_{\mathrm{x}}$ & Poor \\
$\mathrm{X}<\overline{\mathrm{X}}_{\mathrm{i}}-\mathrm{SB}_{\mathrm{x}}$ & Very Poor \\
\hline
\end{tabular}

Data analysis technique of student responses was carried out by converting qualitative data into quantitative data which was in the form of scores by using the Guttman scale. The data that has been converted to the form of scores were then calculated in order to find out the average score of overall and each assessment aspects.

\section{Result and Discussion}

\section{Define}

The first stage is the definition which consists of needs analysis and curriculum analysis. According to needs analysis, the majority of chemistry materials contained abstract concepts so that practicum activity was necessary to support students' understanding. However, not all teachers carried out practicum activities in the learning process due to various obstacles, including equipment and chemicals which are quite expensive; no laboratory assistant who was available; and the busy schedule so that teachers put more emphasis on delivering materials. In addition, the available practicum guideline module has not been able to develop students' soft skills which include problemsolving and creative thinking abilities. Meanwhile, based on curriculum analysis, it was found that the material used in the practicum guideline module containing hydrocarbon compounds, thermochemistry, reaction rates, and chemical equilibrium. The practicum activity on the materials above can be performed simply by using tools and materials which are easily found in everyday life.

\section{Design}

The second stage is design which involves media selection, format selection, reference collection, making instrument of data collection, and making initial design. The initial design of simple chemistry practicum guideline module based on 5-e learning cycle for class XI was compiled by using Canva as well as making covers. The file then was saved as an image (.png) and processed by using Microsoft Word. The components in the developed product consisted of introduction, content, and closing. The introductory section contained an introduction, concept map, module description, instructions for using the module, lab rules, introduction to some lab tools, labels for dangerous symbols, core competencies, and basic competencies. The cover of the simple chemistry practicum guideline module based on the 5-e learning cycle can be seen in Figure 1.

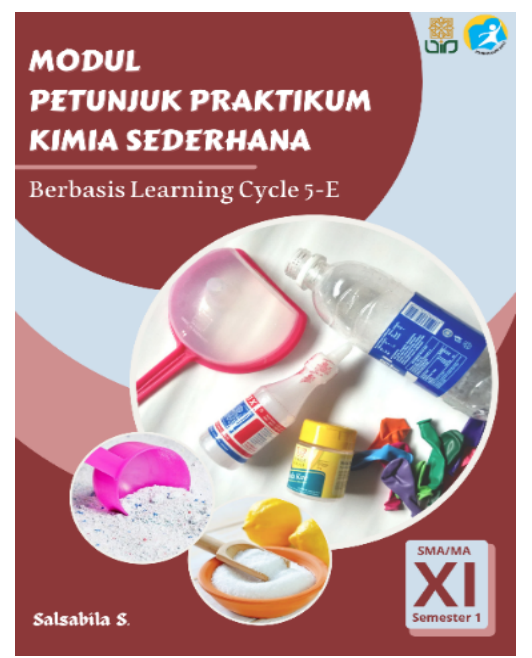

Figure 1. Cover of Practicum Guideline Module

Introduction to several lab tools was presented in the form of a table containing pictures of lab tools along with the names and functions. The presentation of several lab tools aimed to increase students' knowledge regarding various tools and their functions even though students have never seen or used them in the laboratory. Meanwhile, labels of hazardous symbols were also presented in the form of a table that contained descriptions of chemical properties and examples of their compounds. The presentation of hazardous symbol aimed to increase the knowledge and awareness of students when performing practicum activity in the laboratory and working on chemicals labeled with hazardous symbols.
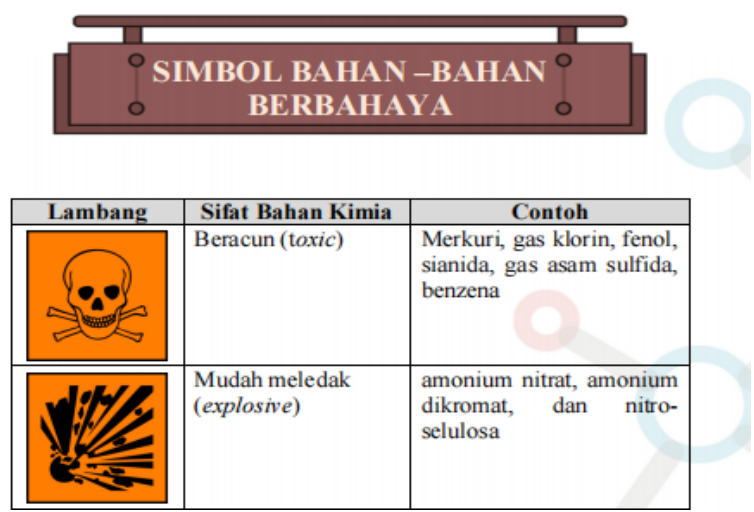

Figure 2. Symbols of Hazardous Chemicals

The content section included seven practicum activities based on sub-chapters of hydrocarbon 
compounds, thermochemistry, reaction rates, and chemical equilibrium. The practicum activities which were presented contained five learning stages (engagement, exploration, explanation, elaboration, evaluation) which were arranged in order to facilitate students in finding out the material concepts. The first stage, engagement (the stage of arousing students' interest and curiosity) contained questions and examples of interesting cases/phenomena presented by using communicative language in order that students were intrigued and they eventually performed practicum activities. Furthermore, an example of the engagement stage in the developed module can be seen in Figure 3.

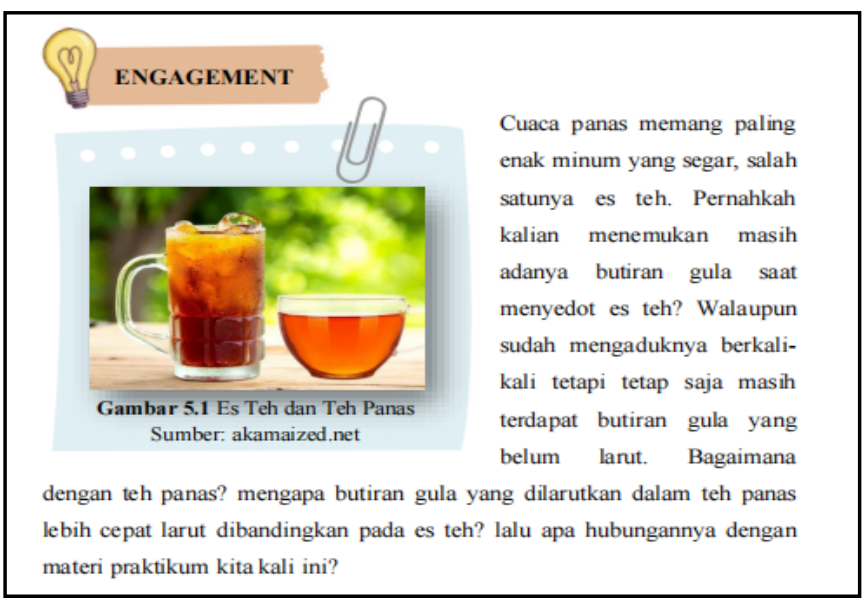

Figure 3. Engagement Stage

The second stage, exploration (inquiry) contained topic-based practicum activity being learned and it included (objectives, basic theory, tools, chemicals, work methods, observational data, and questions to be discussed). Here, the practicum activity used simple work steps as well as tools and chemicals that were easily found in everyday life. In addition, images of a series of tools were included in order that students easily could understand the objectives of work steps presented. In addition, a column containing an invitation to apply affective attitudes was also inserted during the practicum activity. Affective attitudes that were emphasized included habituation of discipline and working together in groups. The column of affective attitude habituation can be seen in Figure 4.

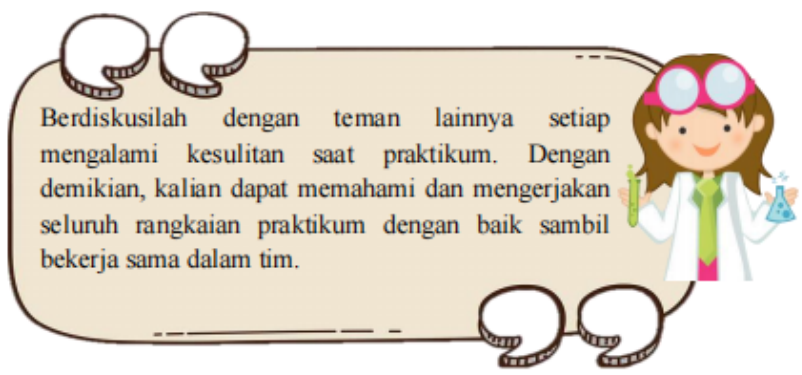

Figure 4. Column of Affective Attitude Habituation
The third stage is explanation. This stage contained encouragement to students in order to explicate their works in practicum activity by using their own language. The fourth stage is elaboration (application). It contained interesting cases/phenomena that were presented in new situations in order to encourage students to apply the concepts that have been obtained. In addition, additional references in the form of barcode images were included. The selection of the barcode image aimed to make it easier for students to access. Students only needed to scan the barcode by using their smartphones. These additional references hopefully could increase students' insight in answering questions at the elaboration stage. The last stage, evaluation (assessment) consisted of exercises and self-reflection. The exercises contained questions that were set to test students' understanding of the obtained concepts through practicum activity. An example of reflection can be seen in Figure 5.

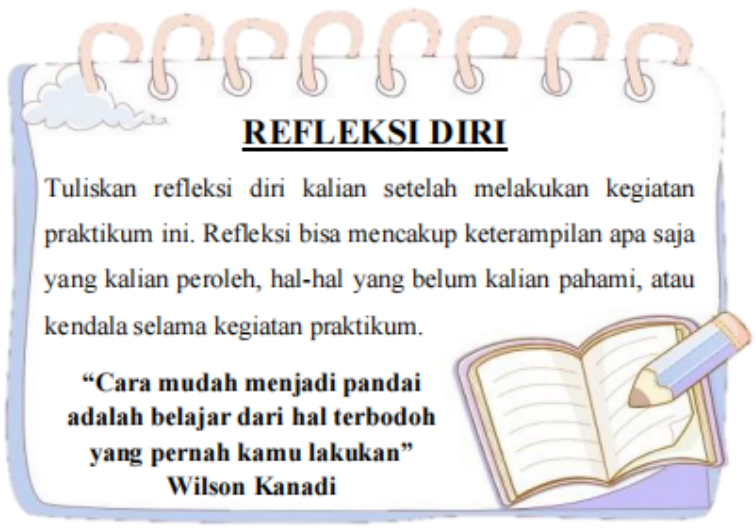

Figure 5. Reflection in the Evaluation Stage

Self-reflection included an overall evaluation of practicum activity from the beginning to the end. In addition, the questions in the engagement stage were also brought up again in the evaluation stage. Furthermore, the closing section contained a bibliography and about the author.

\section{Develop}

5-E learning cycle-based simple chemistry practicum guideline module for class XI were assessed by a material expert. The assessment aspects included aspects of content feasibility, language, and 5-e learning cycle. The results of the assessment by material expert can be seen in Table 2 . 
Table 2. Assessment of Product Quality by Media Expert

\begin{tabular}{llllll}
\hline No. & Assessment Aspects & $\sum$ Score & $\sum$ Ideal Max Score & Ideal Percentage (\%) & Category \\
\hline 1 & Content Feasibility & 13 & 16 & $81.25 \%$ & Very Good (VG) \\
2 & Language & 15 & 16 & $93.75 \%$ & Very Good (VG) \\
3 & Learning Cycle 5-E & 4 & 4 & $100 \%$ & Very Good (VG) \\
Total & & 32 & 36 & $88.89 \%$ & Very Good (VG) \\
\hline
\end{tabular}

Based on Table 2, it can be seen that the quality of the simple chemistry practicum guideline module based on the 5-e learning cycle for class XI is Very Good (VG) with an ideal percentage of $88.89 \%$ and it is feasible according to material expert.
Furthermore, the assessment by media expert was conducted based on two aspects. Those were presentation and the graphics. The results of the assessment by media experts can be seen in Table 3 .

Table 3. Assessment of Product Quality by Media Expert

\begin{tabular}{llllll}
\hline No. & Assessment Aspect & $\sum$ Score & $\sum$ Ideal Max Score & Ideal Percentage (\%) & Category \\
\hline 1 & Presentation & 12 & 12 & $100 \%$ & Very Good (VG) \\
2 & Graphics & 11 & 12 & $91.67 \%$ & Very Good (VG) \\
Total & & 23 & 24 & $95.83 \%$ & Very Good (VG) \\
\hline
\end{tabular}

Based on Table 3, it can be seen that the quality aspect of the 5-e learning cycle-based simple chemistry practicum guideline module for class XI is Very Good (VG) with an ideal percentage of $95.83 \%$ and it is feasible according to media expert.

The assessment on product quality by reviewers (chemistry teachers of high school) was carried out by filling out checklist on the assessment questionnaire. The assessment was conducted by using Likert-scale which was divided into five assessment aspects. The five assessment aspects included aspects of content feasibility, language, 5-e learning cycle, presentation, and graphics. The results of product quality assessments by reviewers can be seen in Table 4 .

Table 4. Assessment of Product Quality by Reviewers

\begin{tabular}{llllll}
\hline No. & Assessment Aspect & $\sum$ Score & $\sum$ Ideal Max Score & Ideal Percentage (\%) & Category \\
\hline 1 & Content Feasibility & 14.8 & 16 & $92.50 \%$ & Very Good (VG) \\
2 & Language & 15 & 16 & $93.75 \%$ & Very Good (VG) \\
3 & Learning Cycle 5-E & 4 & 4 & $100 \%$ & Very Good (VG) \\
4 & Presentation & 11.2 & 12 & $93.33 \%$ & Very Good (VG) \\
5 & Graphics & 11.4 & 12 & $95.00 \%$ & Very Good (VG) \\
Total & & 56.4 & 60 & $94.00 \%$ & Very Good (VG) \\
\hline
\end{tabular}

Based on Table 4, it can be seen the quality aspect of the 5-e learning cycle-based simple chemistry practicum guideline module for class XI is Very Good (VG) with an ideal percentage of $94.0 \%$ and it is already feasible according to reviewers.

The response of students was acquired by filling out the checklist on questionnaire consisting of five aspects, namely content, language, presentation, graphics, and 5-e learning cycle. The questionnaire of student response used the Guttman-scale with the statement "Yes" or "No". There were 10 indicators which contained five positive statements and five negative statements. The results of student responses can be seen in Table 5 .

Table 5. Student Responses

\begin{tabular}{llllll}
\hline No. & Assessment Aspect & $\sum$ Score & $\sum$ Ideal Max Score & Ideal Percentage (\%) & Category \\
\hline 1 & Content Feasibility & 1.8 & 2 & $90 \%$ & Very Good (VG) \\
2 & Language & 1.7 & 2 & $85 \%$ & Very Good (VG) \\
3 & Learning Cycle 5-E & 1.9 & 2 & $95 \%$ & Very Good (VG) \\
4 & Presentation & 1.8 & 2 & $90 \%$ & Very Good (VG) \\
5 & Graphics & 1.8 & 2 & $90 \%$ & Very Good (VG) \\
Total & & 9 & 10 & $90 \%$ & Very Good (VG) \\
\hline
\end{tabular}

Based on Table 5, it can be seen that the ideal percentage obtained is $90 \%$ and it is considered as Very Good category. This means that the 5-e learning cyclebased simple chemistry practicum guideline module for class XI obtained very good response from students. Therefore, it can be concluded that the practicum guideline module which has been developed is feasible to be used as learning media. 


\section{Conclusion}

According to the assessment by material expert, the quality of the 5-e learning cycle-based simple chemistry practicum guideline module for class XI gains an ideal percentage of $88.89 \%$ with the Very Good category. Furthermore, based on assessment by media expert, it obtains the ideal percentage of $88.89 \%$ and $95.83 \%$ with the Very Good category. Thereafter, based on the assessment by reviewers, it gets the ideal percentage of $94.00 \%$ with the Very Good category. Hereinafter, it also receives positive response from students of class XI with the ideal percentage of $90 \%$. Therefore, it can be concluded that that the 5-e learning cycle-based simple chemistry practicum guideline module for class $\mathrm{XI}$ is feasible to be used as a learning media in term of performing chemistry practicum activities in high school. However, the practicum guideline module which has been developed needs to be tested in learning chemistry of class XI, especially in the practicum activity. In addition, it is necessary to develop similar research with different subject matter or chemistry materials.

\section{Acknowledgments}

The authors would like to thank to the supervisor, material expert, and media expert who have taken the time and provided the assessments and advices during developing the product. The author also thanks to the chemistry education students of UIN Sunan Kalijaga Yogyakarta for their contributions in providing suggestions or product improvements. The author would also like to thank to the chemistry teachers and students of class XI who have contributed during collecting the research data.

\section{References}

Adriyani, Z., \& Purwanti, K. L. (2018). Pengembangan petunjuk praktikum IPA fisika-kimia berbasis learning cycle 5E untuk meningkatkan keterampilan proses sains calon guru MI/SD. Thabiea: Journal of Natural Science Teaching, 1(2), 91-101.

https://doi.org/http://dx.doi.org/10.21043/thab iea.v1i2.4073

Amarlita, D. M. (2019). Pengembangan modul praktikum laju reaksi berbasis inkuiri terbimbing. Likhitaprajna: Jurnal Ilmiah, 21(1), 86-91. Retrieved from

https://doi.org/http://likhitapradnya.wisnuwar dhana.ac.id/index.php/likhitapradnya/article/vi ew/145

Baunsele, A. B., Tukan, M. B., Kopon, A. M., Boelan, E. G., Komisia, F., Leba, M. A. U., \& Lawung, Y. D.
(2020). Peningkatan pemahaman terhadap ilmu kimia melalui kegiatan praktikum kimia sederhana di Kota Soe. Jurnal Pengabdian Kepada Masyarakat, 3(4), 43-48. https://doi.org/http://dx.doi.org/10.36257/apts vxix

Faizan, A. (2020). Pengaruh model pembelajaran learning cycle $5 \mathrm{E}$ terhadap hasil belajar materi tatanama. JOM FTK UNIKS : Jurnal Online Mahasiswa Fakultas Tarbiyah dan Keguruan Universitas Islam Kuantan Singingi, 1(2), 302-313. Retrieved from http://www.ejournal.uniks.ac.id/index.php/JO $\mathrm{M} /$ article/view/677

Gotama, P. A. (2018). Soft skill dalam dunia pendidikan pada era Revolusi Industri 4.0. LAMPUHYANG, 9(2), 26-39. https://doi.org/https://doi.org/10.47730/jurnall ampuhyang.v9i2.168

Hendriyani, M. E., \& Novi, R. (2020). Laporan praktikum mandiri dalam bentuk video presentasi untuk mengembangkan kreativitas dan komunikasi lisan di masa pandemi covid-19. Paper presented at Prosiding Seminar Nasional Pendidikan FKIP Universitas Sultan Ageng Tirtayasa,Banten.

Khairunnufus, U., Laksmiwati, D., Hadisaputra, S., \& Siahaan, J. (2018). Pengembangan Modul Praktikum Kimia Berbasis Problem Based Development. Chemistry Education Pratice, 1(2), 36-41.

https://doi.org/http://dx.doi.org/10.29303/cep. v1i2.981

Mulyati. (2020). Penerapan pendekatan pembelajaran saintifik untuk meningkatkan aktivitas dan hasil belajar kimia materi faktor luas permukaan terhadap laju reaksi pada peserta didik kelas XI MIPA 4 SMA Negeri 1 Gemolong tahun pelajaran 2019/2020. Jurnal Pendidikan, 29(2), 109-120. doi: https://doi.org/10.32585/jp.v29i2.747

Pambudi, T., Mulyani, S., \& Saputro, A. (2016). Pengaruh pembelajaran kimia dengan model pembelajaran learning cycle $5 \mathrm{E}$ menggunakan laboratorium real dan virtual ditinjau dari sikap ilmiah terhadap prestasi belajar siswa pada materi pokok hidrolisis garam kelas XI MIPA SMA Negeri 3 Surakarta. Jurnal Pendidikan Kimia, 5(1), 78-87. Retrieved from https://jurnal.fkip.uns.ac.id/index.php/kimia/ar ticle/view/6965

Rahmawati, S., \& Khamidinal. (2019). Buku petunjuk praktikum kimia berbasis green chemistry untuk SMA/MA Kelas XI. Journal of Tropical Chemistry Research and Education, 1(1), 8-14. doi: https:// doi.org/10.37079/jtcre.v1i1.14

Rashidi, A., Fakhrul Adabi, A. K., \& Ilhamie, A. G. A. (2013). Integrating soft skills assessment through 
soft skills workshop program for engineering students at University of Pahang: an analysis. International Journal of Research In Social Sciences, 2(1), 33-46. Retrieved from https://pdfs.semanticscholar.org/2ba6/0b7f18a1 465f571128b46f7ce560c8cbc593.pdf

Redhana, I. W. (2019). Mengembangkan keterampilan abad Ke-21 dalam pembelajaran kimia. Jurnal Inovasi Pendidikan Kimia, 13(1), 2239-2253. Retrieved from https://journal.unnes.ac.id/nju/index.php/JIPK /article/view/17824

Samad, S. (2020). Pengembangan Soft Skill Peserta Didik. Paper presented at Seminar Nasional Hasil Pengabdian kepada Masyarakat, Universitas Negeri Makassar.

Sugiharti, S., \& Sugandi, M. K. (2020). Laboratorium virtual: media praktikum online untuk meningkatkan pemahaman siswa di masa pandemi. Paper presented at Seminar Nasional Pendidikan FKIP UNMA, Majalengka.

Suryaningsih, Y. (2017). Pembelajaran berbasis praktikum sebagai sarana siswa untuk berlatih menerapkan keterampilan proses sains dalam materi biologi. Bio Education: The Journal of Science and Biology Education, 2(2), 49-57. doi: http://dx.doi.org/10.31949/be.v2i2.759

Widyasti, N. M. ., Wiratma, I. G. L., \& Muderawan, I. W. (2020). Uji validasi pengembangan lembar kerja siswa berbasis pendekatan saintifik. Jurnal Ilmiah Pendidikan Dan Pembelajaran, 4(1), 79-85. doi: http://dx.doi.org/10.23887/jipp.v4i1.15591

Wisetya, M. A. B., \& Ismara, K. I. (2018). Penerapan strategi pembelajaran cooperative learning terhadap soft skills interpersonal siswa. E-Journal Universitas Negeri Yogyakarta, 8(1), 17-24. Retrieved from http://journal.student.uny.ac.id/ojs/index.php/ elektro

Yuliati, Y., \& Saputra, D. S. (2019). Pembelajaran sains di era revolusi industri 4.0. Jurnal Cakrawala Pendas, 5(2), 167-171. doi: https://doi.org/10.31949/jcp.v5i2.1389

Yuniar, S. A., Zammi, M., \& Suryandari, E. T. (2019). Pengembangan petunjuk praktikum berbasis green chemistry pada materi stoikiometri kelas $X$ di SMAN 7 Semarang. Journal of Educational Chemistry (JEC), 1(2), 51-61. doi: https://doi.org/10.21580/jec.2019.1.2.4235 